\title{
Prato: The Social Construction of an Industrial City Facing Processes of Cultural Hybridization
}

\author{
Andrea Bellini and Laura Leonardi
}

\begin{abstract}
This chapter deals with a widely studied case, that is, Prato, a middle-sized city with rooted industrial traditions, in the Centre of Italy. Prato is a textile industrial district embedded in the so-called Third Italy - an area characterized by the presence of small firms spread throughout the territory, linked together in supply and subcontracting relationships - which, in the last twenty years, has undergone a profound transformation as a consequence of the crisis of textile and immigration, leading to the formation of a large Chinese community. The related changes brought with them problems of social cohesion and sustainable development. The authors address these issues by analyzing both academic and public discourses on Prato. Their basic idea is that common stereotypes act as drivers of a public discourse that prevents the city to re-negotiate its identity. The analysis concludes that different forms of hybridization-particularly cultural hybridization—are occurring, which would need further investigations.
\end{abstract}

\section{Keywords}

Industrial district · factory city · Chinese immigration · environment · landscape stereotypes $\cdot$ Covid-19 $\cdot$ cultural hybridization

\footnotetext{
A. Bellini $(\bowtie) \cdot$ L. Leonardi

Università degli studi Firenze, Firenze, Italy

e-mail: andrea.bellini@unifi.it

L. Leonardi e-mail: laura.leonardi@unifi.it

(C) Springer Fachmedien Wiesbaden GmbH, part of Springer Nature 2020

D. Edler et al. (eds.), Modern Approaches to the Visualization

of Landscapes, RaumFragen: Stadt - Region - Landschaft,

https://doi.org/10.1007/978-3-658-30956-5_30
} 


\section{The City of Prato in the 21st Century: A Short Introduction}

Prato is a middle-sized city with rooted industrial traditions. It is located in the North of Tuscany, in the Centre of Italy. Despite its being embedded in a metropolitan area and its proximity to Florence, it distinguishes itself for a strong identity, built around the idea of industrial district. This term refers to a form of development characterized by the territorial concentration and sectoral specialization of a high number of small and mediumsized firms or, to put it with its earliest promoter, Alfred Marshall (1890, p. 198), a place with an industrial atmosphere, where "the mysteries of the trade become no mysteries, but are as it were in the air". It was, then, reprised and developed by the Florentine economist Giacomo Becattini (1962, 1979, 1987, 2004) and other eminent scholars (Bellandi and Russo 1994; Brusco 1989; Trigilia 1986; Viesti 2000). It is no coincidence that these authors, first and foremost Becattini (1997, 2000), devoted special attention to Prato, considered as the archetype of Italian industrial districts.

As such, Prato is part of the so-called Third Italy (Bagnasco 1977), referring to the particular trajectories of socioeconomic development of the regions of the Centre and North-East, distinct from the North-West and the South of the country. This type of development is characterized by the presence of small firms spread throughout the territory, linked together in supply and subcontracting relationships. This structure is highly flexible and, during the 1970s and 1980s, demonstrated a greater capacity to adapt to globalization's challenges. The changes that occurred over time in the distribution of economic activities and of the population in the metropolitan area had a significant impact on the city, modifying its functions and morphology.

In the last twenty years, in fact, Prato has undergone a profound transformation as a consequence of the enduring crisis of its productive specialization, that is, the textile industry, and of migration dynamics, which led to the formation of the second-largest Chinese community in the country after Milan. While it has not abandoned its industrial vocation, Prato deals with the tertiarization of its economy and its becoming more and more multicultural. These changes brought with them problems of social cohesion. Furthermore, they would imply re-negotiating the identity of the city.

This chapter addresses the above issues by analyzing the discourses on Prato, focusing on the stereotypes that make it difficult to confront the processes of change in a way that allows the renovation of the public image of the city. For this purpose, we proceed as follows. In Sect. 2, we draw a historical, geographical, and socioeconomic outline of Prato, to introduce the case. In Sect. 3, we present a literature review aimed at identifying thematic patterns in academic research. In Sect. 4, then, we investigate social representations through an analysis of Internet videos, as practical means for the social construction of places (see in this volume: Kühne 2020; for movies in general: Papadimitriou 2020; for internet images: Linke 2020; Loda et al. 2020; for introductory remarks on the current media availability: Edler et al. 2020). After a brief description of the research strategy, we examine the main patterns of representation and related 
landscape stereotypes. Drawing on Kühne's (2018, 2019) constructivist approach, we look at the landscape - specifically urban landscape - in its dual character of "individual construct based on social patterns of interpretation and evaluation" (Kühne et al. 2019, p. 78). In this sense, landscape is a 'mediating' concept, which allows us to understand how the reality 'as it is' is interpreted by individuals and translated into collective meanings, of which stereotypes are accessible codifications (Kühne and Bellini 2019; see in this volume: Kühne and Jenal 2020). In the concluding section, we compare academic and public discourses to get inputs to refine the research agenda. More generally, we reflect on how to redraw the picture.

\section{Historical, Geographical, and Socioeconomic Sketches}

Prato is a city with a long history. The first human settlement in the area where the city stands today was of the Etruscan era. The foundations of the city, however, date back to the Middle Age, and the name Prato came into use in the 11th century. At that time, the rivalries with the neighboring cities gave rise to frequent conflicts, through which the city gained the status of a free commune. In the subsequent centuries, however, Prato was subjected to foreign dominations. In 1351, it passed to the Florentine Republic, although preserving a certain autonomy and further developing its identity. In those years, Francesco di Marco Datini, also known as the Merchant of Prato, conducted his businesses, mostly in textile products' manufacturing and trade. Afterward, Prato continued to grow and maintain a balance between city and countryside, at least until the half of the 19th century, when the transition from an artisan to an industrial mode of production took place. Between the two world wars, then, Prato was an important industrial city, although it was in the second post-war period that it achieved its fame.

Prato differs from other areas of Tuscany because of the presence of widespread entrepreneurship in the industrial sector, whose origins, nevertheless, are in the type of organization of the agricultural sector that characterized it in the past. Small farms guided by sharecroppers (mezzadri), helped to form competencies and skills, but also a labor culture, which was functional to the transition to industrial entrepreneurship. Since the beginning, Prato is known as the 'city of rags' (città degli stracci) for the recycling of used fabrics, which became its distinguishing feature. Family-run micro-firms initially formed inside the houses, in the urban context. For this reason, a typical representation of Prato is that of a 'factory city' (città fabbrica), in which there is no solution of continuity between home and place of production.

From 1950 to 1980, the number of textile workers grew at a steady pace. The development of Prato was based on a widespread culture linked to a work ethic, the centrality of the family, the sharing of political values - the 'red' political subculture (Trigilia 1986), linked to resistance to fascism-and the presence of deep-rooted civil associationism, which allowed for administrative continuity. The city developed around its industrial core attracting workers from other regions, most of them from Southern Italy, 
guaranteeing them full citizenship, with integration into the production system and the local society. Inward migration flows reshaped the urban environment giving rise to new neighborhoods and industrial areas and laying the foundations for a polycentric development, which became more accentuated with the arrival of Chinese immigrants during the 1990s. That said, the decade between the 1980s and the 1990s was a period of decline, which led to a downsizing of the district and its repositioning in international markets, with a partial relocation of production abroad in Eastern Europe. A reversal of this trend coincided with the arrival of the Chinese, who brought some phases of production back in Prato, reducing transaction costs.

Geographically, Prato is located in the center of a metropolitan area that covers more than $1,200 \mathrm{~km}^{2}$ from Pistoia to Florence and counts over 1 million inhabitants. As such, it is at the center of one of the most important commuting areas in Tuscany (see: Fig. 1). The city of Florence is the major pole of attraction. More than 10,000 people, indeed, commutes from Prato to Florence every day for business purposes. A more limited, bidirectional flow connects Prato with Pistoia (Iommi and Marinari 2020).

The proximity to Florence and the possibility to commute to work, associated with the rise in real estate market prices in the capital of Tuscany, partly explains the increase in the number of inhabitants of Prato, now close to 200,000. The rise in the number of foreign residents also contributed to this growth. Foreigners, indeed, are over 40,000 (more than 20 percent of the resident population); among them, almost 25,000

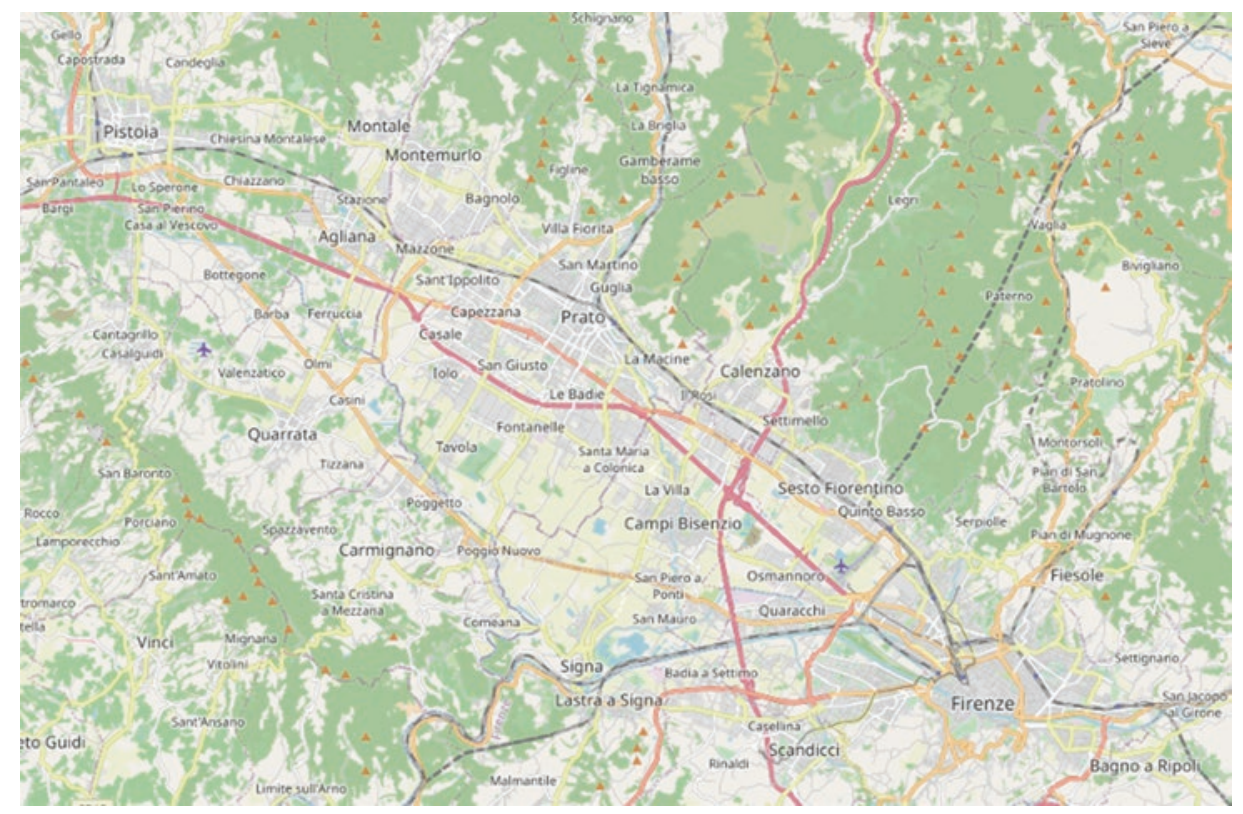

Fig. 1 Map of the metropolitan area of Pistoia-Prato-Florence. (Source OpenStreetMaps (https:// www.openstreetmap.org/); image retrieved on May 18th, 2020.) 
(12 percent of the total) are Chinese people (source of data: Municipality of Prato, at December 31st, 2019). It is worth noting that the increase of foreigners rather than offset the decrease of natives allows the population to continue to grow.

The configuration of the city also changed considerably. Due to the presence of mountains that draw a physical border at the North-East and tighten the city in a funnel that flows into the Bisenzio Valley in the North, Prato expanded from the North-West to the South-East, where the white roofs of the factories replaced green fields (see: Fig. 2). The creation of new industrial areas outside the urban perimeter aimed to overcome the model of factory city.

This process met increasing difficulties because of the concentration of Chinese immigration in the so-called 'Macrolotto 0', adjacent to the city center. This implied the reproduction of the old model of urban development. Figure 3 gives an idea of how the Chinese community occupied the territory. It is known, in fact, that there was a tacit division of labor between Italian and Chinese firms, with the former concentrated in textile, the latter in apparel. As Fig. 3 shows, apparel firms spread throughout the city occupying the same areas as textile firms, but with a higher concentration in the 'Macrolotto 0' (in the middle of the picture on the right) and the 'Macrolotto 1' (below the red line, that is, the artery that connects Pistoia, Prato, and Florence).

Figure 4 gives further information on the spatial distribution of the population, focusing on the distribution of socioeconomic disease. The map on the left-divided into basic statistical units, similar to neighborhoods-reveals that wealthy areas are concentrated

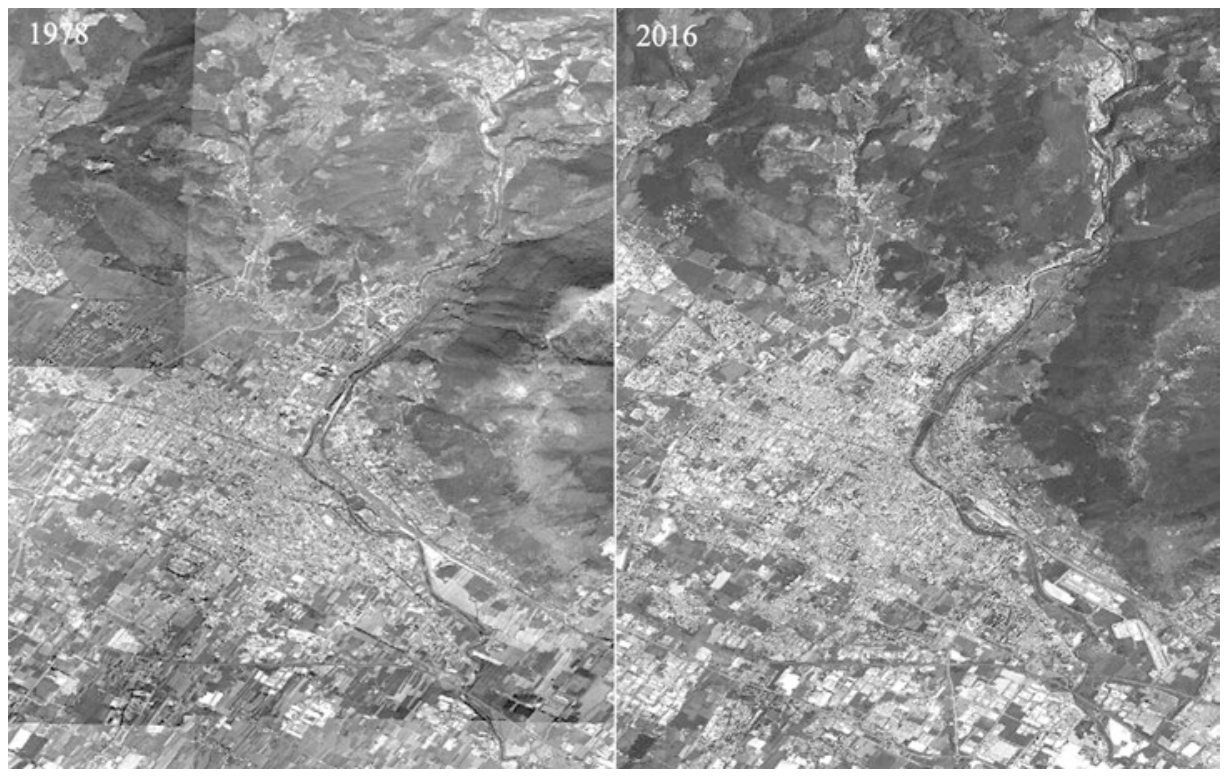

Fig. 2 Aerial photos of the city of Prato, in 1978 and 2016. (Source Municipality of Prato, GeoServer Web Map Service) 


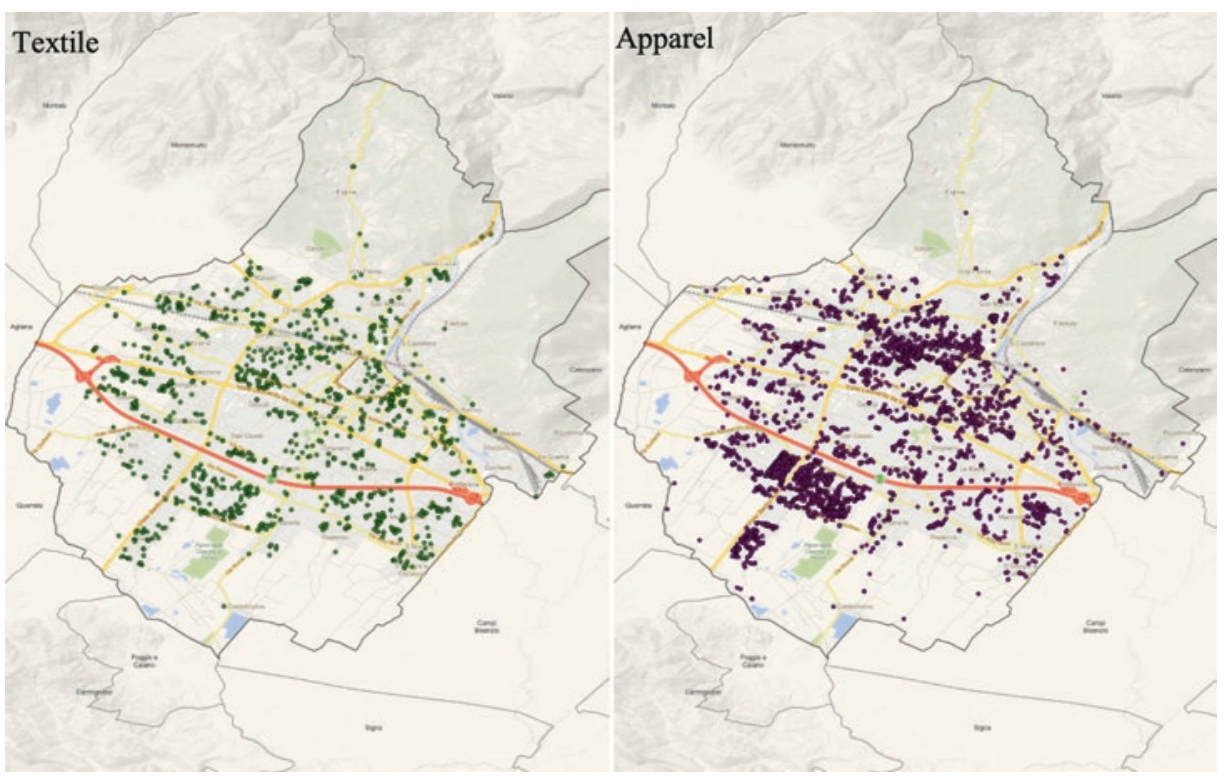

Fig. 3 Spatial distribution of textile and apparel firms. (Source Municipality of Prato, GeoServer Web Map Service)
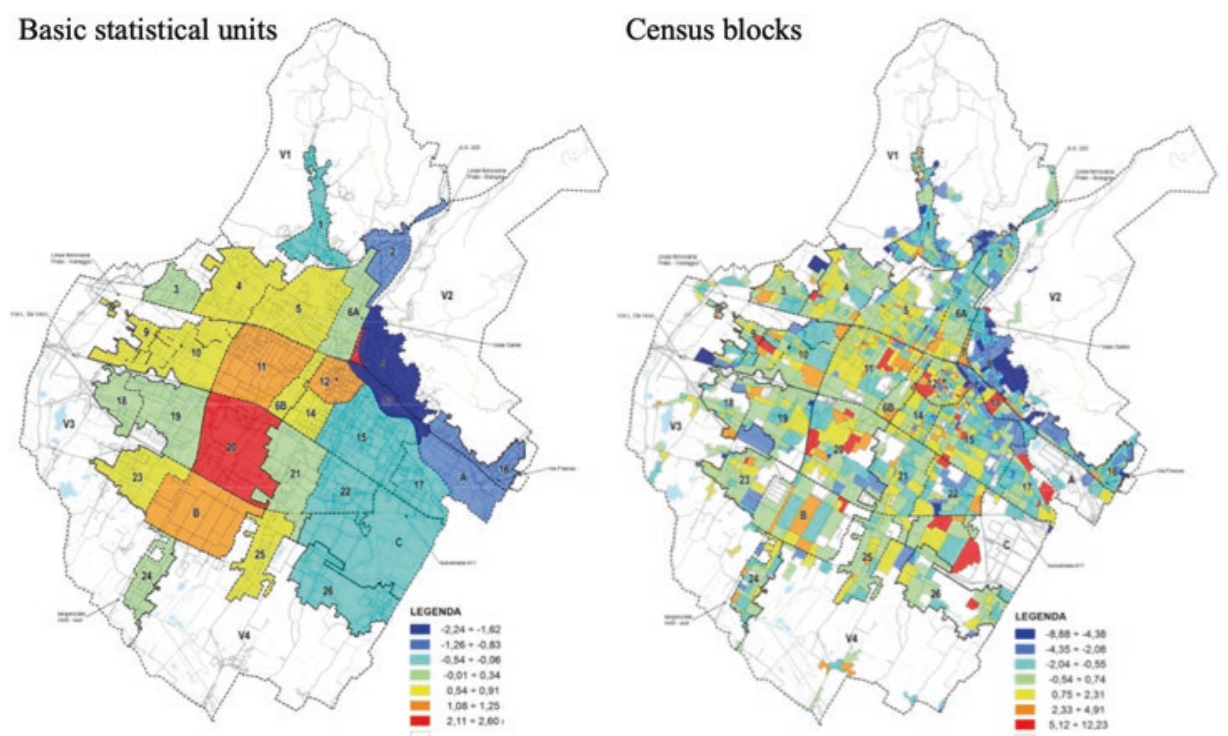

Fig. 4 Spatial distribution of socioeconomic disease (deprivation index, 2011). [Notes (1) the index used is that created by Caranci et al. (2010), applied to data from the 2011 Census of Population and Housing; (2) it is a sum of the frequencies of five variables, namely low level of education, unemployment, one-parent family, and home rental and home overcrowding; (3) a higher value indicates higher deprivation. Source Statistical Office of the Municipality of Prato (2015, pp. 8, 11)] 
in the North-East (units 2, 8, 13, A, in dark tones of blue). The Bisenzio River takes on the role of a physical barrier that isolates 'bourgeois' residential areas. If we compare Figs. 3 and 4, it is evident that these are the only areas where living spaces are clearly separated from the places of production. On the other hand, the map on the rightbased on smaller units, namely census blocks - depicts the rest of the city as a mosaic, where clear-cut patterns cannot be recognized except that at the level of small areas, such as that between Via Filzi and Via Pistoiese (unit 11, red and orange blocks), that is, Chinatown.

Since the 1990s, the city of Prato has faced increasing social cohesion problems, combined with the textile industry's crisis and the expansion of the Chinese community. The local production system has changed significantly, having undergone a process of tertiarization, only in part related to textile. The global crisis of 2008 intensified this trend. Now, two different paths of development can be identified based on manufacturing and services. Another constitutive element of the district identity is in question. The roots of the 'red' subculture, in fact, have become weaker. In this regard, clear signs came from the electorate, which reoriented its vote in a more volatile manner, resulting in an unprecedented alternation of right- and left-wing coalitions to the government of the city.

To sum up, the long history of Prato, its character as an industrial and, increasingly, multicultural city, together with the processes of change that have taken place, make it a case of great interest, today more than ever. The tension between continuity and change is evident in the tie the people have with the past, based on rooted stereotypes. Our idea is that common stereotypes act as drivers of a public discourse that prevents the city to renegotiate its identity. In the following sections, we investigate this issue by analyzing the discourses on Prato and the underlying stereotypes.

\section{A Lively Academic Debate: A Multidisciplinary Literature Review}

Preliminarily, we conducted a literature review to identify thematic patterns in academic research. We performed the literature search in February 2020 in Web of Science (WoS), a widely recognized and trusted multidisciplinary database, which gathers a large number of high-quality research products.

As a starting point, we entered the following criteria in the search engine: search string [topic] (Prato); timespan [custom year search] (2000-2019); search language (English). The choice of the reference period finds justification in that, since the early 2000s, the effects of the crisis of textile and of immigration have become evident. As noticed, these processes have transformed Prato profoundly. Instead, English was a forced decision since we aimed to make this work comprehensible for the broadest possible audience.

Subsequently, we refined the search by restricting it to journal articles and removing 'false positives'. Articles, in effect, are shorter and more focused than other academic products, such as monographs; this makes them more suitable for identifying thematic 
patterns. A further selection was needed, due to the presence of articles that reported 'Prato' as a keyword, although with different semantic values.

The application of these criteria yielded a total of 72 publications, classified in 75 research areas. Most of them were articles of 'Environmental Sciences Ecology' and 'Public Environmental Occupational Health', followed by 'Geography', 'Business Economics', 'Toxicology', 'Demography', and many others.

Three preliminary remarks must be made here. First, Prato is the subject of a lively academic debate. Second, this debate finds space in influential international journals, which indicates that Prato is a breeding ground for research in different disciplinary areas. Third, environmental sciences hold a primary position on this ground.

Once we completed the selection process, we used a computer-assisted qualitative data analysis software-i.e., QSR NVivo 12 Plus for Windows (see: Bazeley and Jackson 2013) - to store, manage, code, and explore the texts. As a first step, we coded the data sources and created two project items, which gathered together keywords and abstracts, respectively. After that, we ran a word frequency query in the 'keywords' item. The search identified 320 words that, for simplicity, were displayed in a word cloud (see: Fig. 5, below). Then, we read through the list and further selected 50 terms, grouping those with

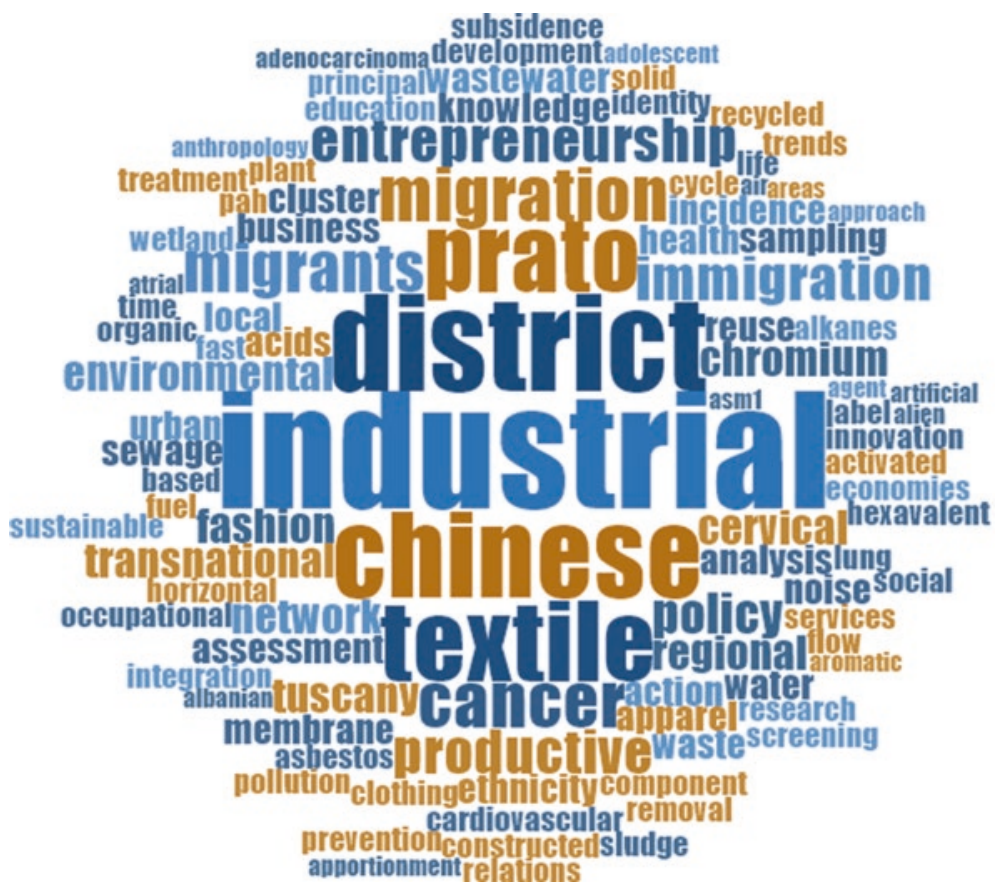

Fig. 5 Word cloud of the most frequently used keywords in journal articles. Note: based on a word frequency query limited to words with a minimum length of 3 characters and stemmed words. (Source authors' processing of the texts of selected articles retrieved from WoS on February 23rd, 2020) 
similar meanings. We ran text searches in the 'abstract' item on each of them and created results as nodes. Finally, we drew a map relating themes (nodes) to articles (cases) to identify thematic patterns (see: Fig. 6, below).

As Fig. 5 shows, the most frequently used keywords are 'industrial OR industry' and 'district OR districts', followed by 'Chinese' and 'textile OR textiles'. These terms refer to typical representations of Prato as a textile industrial district and a city that hosts a large Chinese community. Unexpected indications come from other keywords, such as 'cancer', 'chromium', 'environmental', 'health', 'noise', 'reuse', 'sewage', 'waste', 'wastewater', 'n-alkanes', 'asbestos', 'hexavalent', and 'pollution'. These terms relate to challenging discourses, worth exploring.

The analysis revealed the existence of six patterns built around six main themes, reported in Fig. 6, numbered from 1 to 6 from most to least significant: (1) district; (2) production, primarily referred to the textile industry, (3) immigration, related to the tale of the Chinese community; (4) policy; (5) environment; (6) wastewater.

The map shows, that these patterns are related to each other, but three of them-numbered from 1 to 3-are interconnected to such an extent that they may be considered as a unique, broader pattern. Most of the studies converged on the district dimension, either developing a meta-reflection on the inherent nature of an industrial district, analyzing its specific mode of production, or focusing on the migrant population, which works in these sectors, primarily composed of Chinese people. The district also lies behind other patterns. Local development policies, for instance, are a constitutive element of the model of governance of the district. Being an industrial city, then, implies dealing with

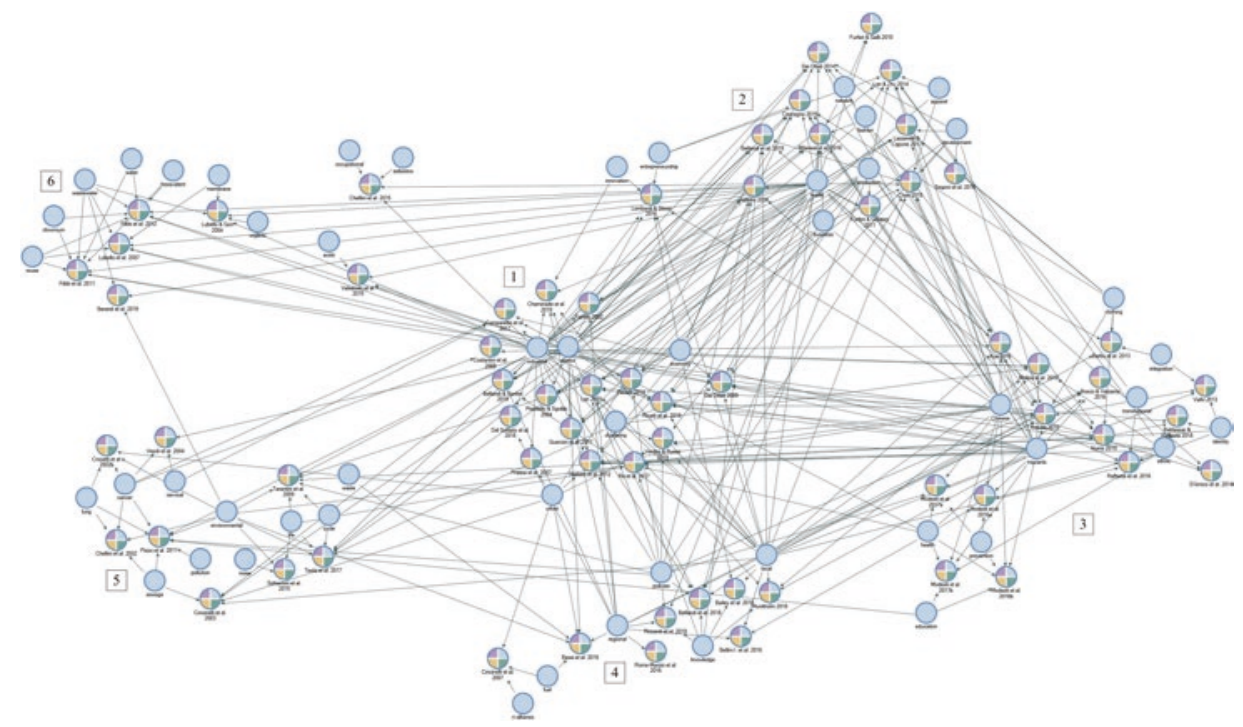

Fig. 6 Map of thematic patterns. (Source: authors' processing of the texts of selected articles retrieved from WoS on February 23rd, 2020) 
environmental issues related to pollution and sewage disposal, which are, in turn, connected with severe health problems such as cancer.

In detail, the district pattern emphasizes the specificity of Prato as a Marshallian industrial district. Several studies reviewed in this chapter refer to this concept (Bellandi et al. 2019; Bellandi and Santini 2019; Chaminade et al. 2009; Dei Ottati 2009, 2014; Fioretti 2002; Lan 2015; Milanesi et al. 2016). Though, a dominant thematization is that looking at the transformation of the district, as a consequence of the decline of the textile industry (Adamo 2016; Bellandi and Santini 2019; Bellandi et al. 2018; Chaminade et al. 2009; Dei Ottati 2009) and the expansion of the Chinese community (Ceccagno 2015; Lan 2015; Ricatti et al. 2019; Verdini and Russo 2019).

The production pattern looks specifically at economic aspects (Bailey et al. 2010; Bellandi et al. 2019; Lazzeretti and Capone 2017; Milanesi et al. 2016) and technological issues (Furferi and Gelli 2010; Furferi and Governi 2011), concentrating on sectoral dynamics in the textile, apparel, and fashion industries. Furthermore, some studies analyze the role of Chinese firms in reorganizing production and repositioning the district in the global value chain (Chen 2015; Dei Ottati 2014; Lan and Zhu 2014).

A definite immigration pattern, however, developed in parallel, focusing on the problems related to the integration of Chinese people (Baldassar and Raffaetà 2018; Bracci and Valzania 2016; Raffaetà et al. 2016) and their forms of entrepreneurship (Barbu et al. 2013; Krause 2015; Molina et al. 2018). A singular thematization has arisen in the field of medicine. Here, the interest is due to the empirical evidence that, in European countries, ethnic minorities tend to have higher health risks than autochthone populations (Modesti et al. 2016a, b, 2017a, b).

Then, the policy pattern is represented by contributions that address particular issues, shifting the attention from district to urban governance, dealing with the unwanted consequences of industrial production and immigration. Besides those focusing on local development, thus, we find studies referring to urban regeneration policies adopted to combat the social segregation of Chinese people (Verdini and Russo 2019), and policies against illegality, again connected with the presence of a large ethnic minority and the related cultural conflicts (Munkholm 2018; Riccardi et al. 2019). Others focus on the problem of management and recovery of urban waste, with specific attention to the waste produced in industrial areas (Bessi et al. 2016; Tarantini et al. 2009; Testa et al. 2017).

A substantial group of articles is framed in the environment pattern. Part of them addresses the problem of air pollution, connected with the concentration of atmospheric aerosols, a great matter of concern in urban and industrialized areas due to their toxic and carcinogenic properties (Cincinelli et al. 2003, 2004, 2007; Pratesi et al. 2007). Another part deals with the risk of cancer, indeed, related to environmental pollutants (Chellini et al. 2002, 2015; Crocetti et al. 2002a, b; Crocetti et al. 2001; Pizzo et al. 2011; Seniori Costantini 2008; Visioli et al. 2004). Among other relevant environmental issues is noise pollution (Schiavoni et al. 2015). 
The wastewater pattern, finally, is worth a separate mention. The treatment of wastewaters, in fact, is strategic in the context of an industrialized area where a large part of wastewaters comes from the textile industry (Berardi et al. 2019; Fibbi et al. 2011, 2012; Lubello et al. 2007; Lubello and Gori. 2004; Valsecchi et al. 2015).

To conclude, the analysis returned an all-round image of Prato, as a complex city affected by multiple problems. On the other hand, this operation did not allow us to overcome the monolithic representation of Prato as a textile industrial district. Quite the opposite, the academic discourse and its manifold thematizations developed from this central theme.

\section{Social Representations of a City in Transformation: An Analysis of INTERNET Videos}

\subsection{Brief Methodological Notes}

In the following pages, we investigate how the city of Prato is represented in Internet videos, looking at how urban landscape is constructed and how stereotypes are produced (on the social construction of landscape see: Kühne 2019). Specifically, we searched and analyzed YouTube videos, as YouTube is one of the most important video-sharing platforms, offering a wide variety of user-generated and corporate videos. We performed the search in April 2020.

There follows a description of the search strategy and analytical methods. First, we installed a clean search browser to exclude progression-related pre-selections and avoid distortions due to personal and location settings. Second, we entered the following criteria in the search engine: search string (Prato); type (video); sort by (relevance). Third, we selected the fifty most relevant videos, being careful to rule out false positives. After a first summary analysis of the results, we decided to exclude 14 sports videos-these were brief journalistic reports on sporting events that made no significant references to the city and urban landscape - and we replaced them with the next 14 videos in order of relevance. Fourth, we captured the videos with QSR NCapture, a web-browser extension that enables us to gather web content to import into NVivo. We, then, imported the videos into NVivo and classified them on the basis of 8 variables, grouped as follows: technical aspects (the type of product and degree of professionalism); and content-related aspects, further divided into general (the type of contents, the intensity of specific spatial references, and the degree of stereotipicity) and issue-specific (the intensity of references to industrial identity, immigration, and the past). After that, we conducted a descriptive analysis of the database aiming to identify essential aspects related to the dominant themes and the associated spatial stereotypes. Fifth, we further selected six videos to analyze in depth, taking into account the variety of contents. In particular, we focused on recurrent subjects, themes, and spaces to understand how their symbolic values translate into stereotypes, which, in turn, contribute to constructing the public image of the city. 


\subsection{Patterns of Representation}

The selected Internet videos were published from 2007 to 2020. Choosing videos based on relevance meant that the most recent videos were overrepresented; indeed, 22 out of 50 are published in 2019 and the first three months of 2020. The number of views varies considerably, between 4 and 1,274,003. Instead, the length is under half an hour, the types of products being constituted almost exclusively by relatively short videos and a small number of excerpts from documentary films.

Interesting indications come from the examination of the degree of professionalism in the implementation of the videos (see: Fig. 7). To categorize the videos, following Kühne in this book, we took as references-in terms of editing, image, and sound quality-the standard of a national news channel for a 'professional realization' and of an amateur video for an 'unprofessional realization'. Here, it is worth noting that 16 out of 50 videos are classified as professional realizations, mostly consisting of journalistic reportages and excerpts from daily news launched by national tv channels, which means that Prato finds space in the national media. Stereotypes play a primary part in constructing a public image that is closely connected with discourses developed at the national level-e.g. concerning immigration-and leaves it open to political exploitation. The comparison with the realizations approaching professionalism, such as those consisting of excerpts from the daily news of local tv channels, reveals that stereotypes are handled differently at the two levels: indeed, to reinforce a public or political discourse, at the national level; to deal with concrete problems, but neutrally, at the local level. Here, a counterintuitive finding is that the higher is the degree of professionalism, the more stereotypes have a constitutive effect.

In terms of content, 12 inductively obtained categories can be identified: advertising videos; amateur videos; daily news; documentaries; food-related videos; journalistic reportages; movie trailers; music videos; photo collections; satirical videos; videos for territorial marketing; travel videos. Among them, journalistic reportages prevail.

Different contents are related to different ways of approaching space. Space is represented in most videos, although with a different intensity, being frequently conducive to action or thematized (see: Fig. 8). This is truer for amateur videos and documentaries, while, in journalistic reportages and daily news, space tends to play a secondary part. Here, again, a difference can be observed, since journalistic reportages, especially when transmitted by national tv channels, more often thematize space. In this case, stereotypical references to Chinatown and the Chinese community prevail.

Immigration, indeed, is one of the most referenced themes (see: Fig. 9). Besides, references to places or issues related to the industrial identity remain in the background, while another constitutive theme is connected to the idea of a 'lost' past. In effect, these three themes are somewhat interrelated in a coherent field of meaning. The nostalgic references to the past, indeed, rely on spatial stereotypes that have to do with the industrial identity. In this case, space is conducive to action, and stereotypes have a constitutive 


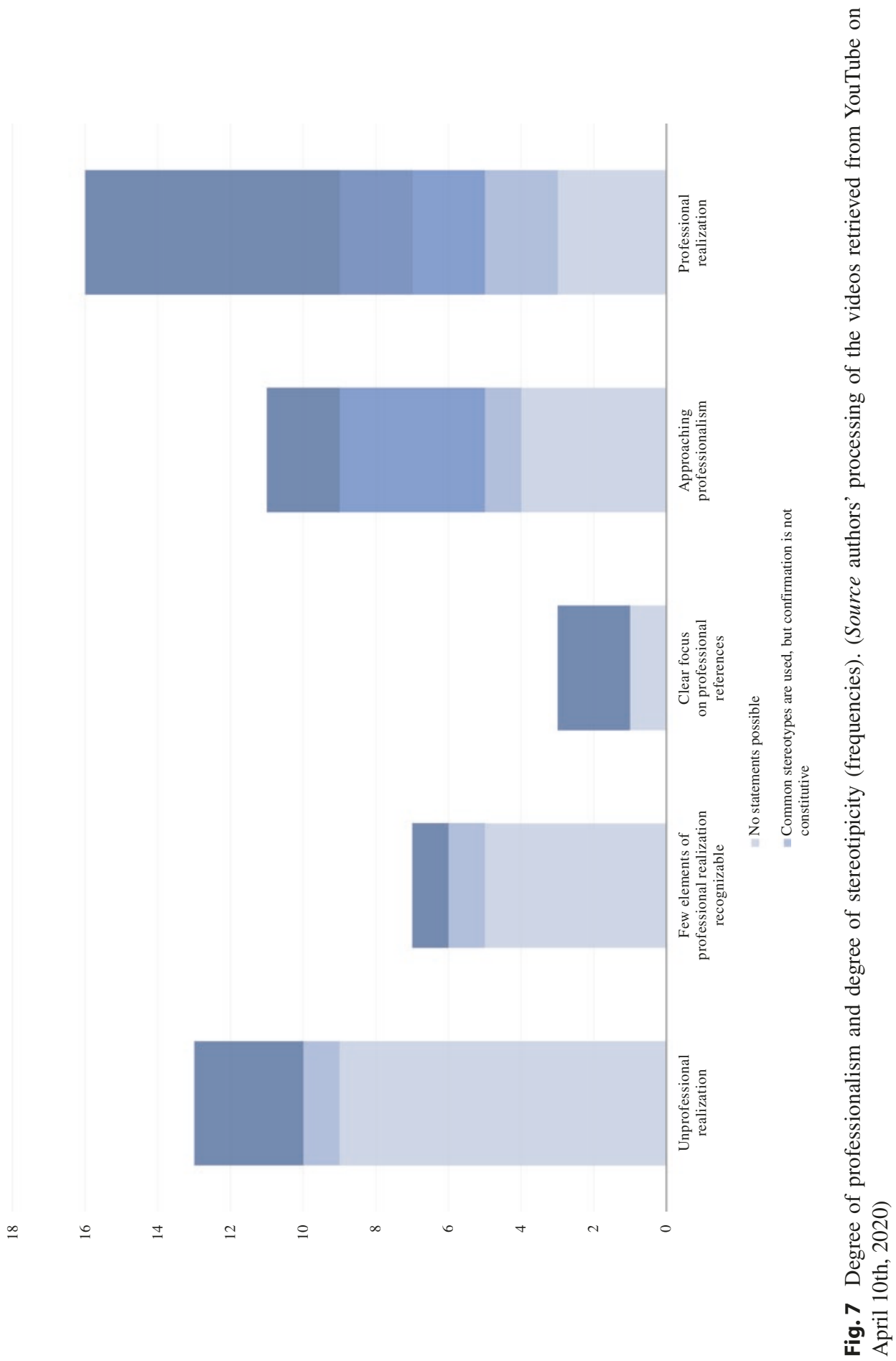




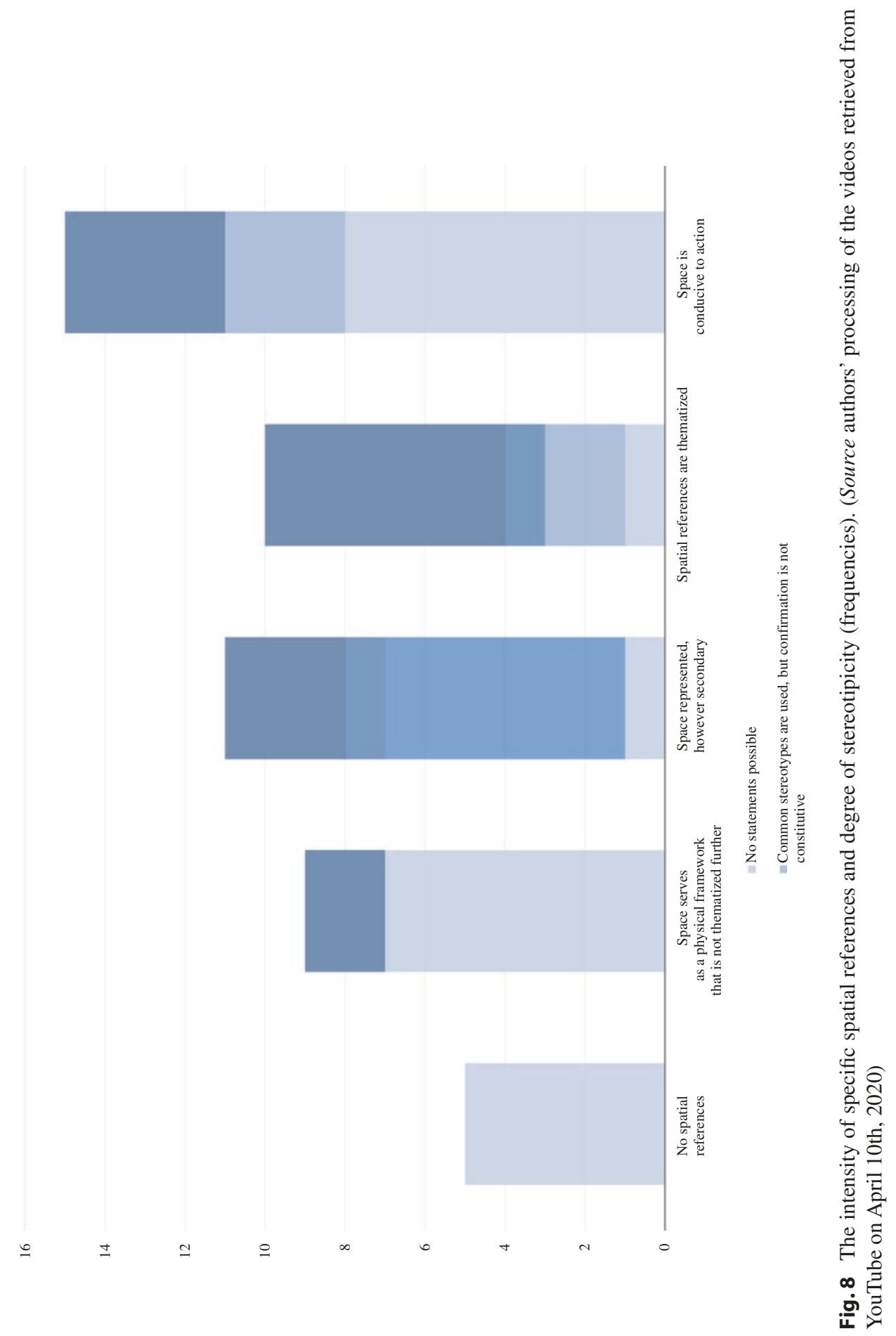




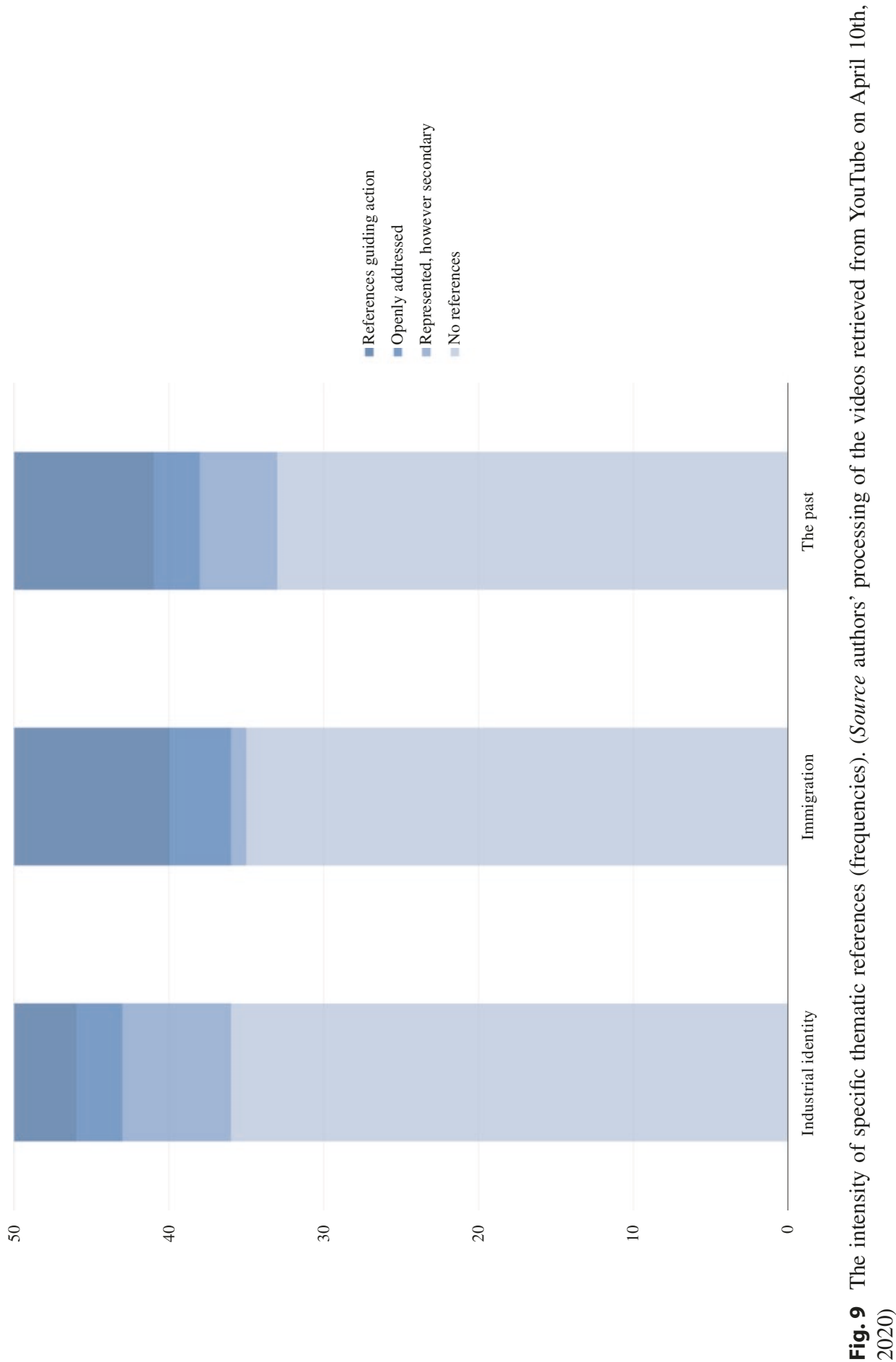


effect, although these are, in a sense, 'neutral' stereotypes, not implying the use of a discriminatory language. Instead, immigration is seen as a threat to the industrial identity, contributing to the city losing its past. This view, in truth, emerges as a minority, though amplified by the national media.

Generally speaking, stereotypes are very present. Moreover, they have more often a constitutive effect when they rely on connotative or thematized spatial references, and when immigration is the focal theme.

That said, in inductive research design, the analysis of the deviance from the norm is as significant as that of recurrences. From this perspective, some minor thematic patterns are of great significance. These patterns rely on 'new' aesthetic references, such as those to historical heritage, cultural sights, modern art, and good food, which are struggling to replace 'old' aesthetic stereotypes related to the symbolic signs of the industrial and multi-ethnic identity of Prato. These patterns are also put forward as a strategy of territorial marketing to change the public image of the city.

Nevertheless, this process has encountered a challenging obstacle in the further strengthening of the immigration pattern, to which are connected stronger stereotypes. The Covid-19 pandemic that spread in early 2020 gave new relevance to this discourse. Since the pandemic originated in China, and 1,500 to 2,500 persons were expected to come back after participating in the Chinese New Year festivities in the country of origin, Prato was under watch. The videos addressing this issue, also those handling common stereotypes neutrally, testify the concern of local authorities. However, Prato has proven to be able to respond better than the neighboring cities to this emergency, primarily thanks to the Chinese community, which anticipated the Italian government's restrictive measures and placed itself in self-quarantine. At the time of writing, Prato is one of the cities with a lower number of cases of contagions and deaths related to Coronavirus in the Centre-North of the country. Of course, this does not prove any causal relationship between the two phenomena, while it reveals that what we know about the Chinese community in Prato is mostly based on stereotypes. The Chinese, in Prato, are often stereotyped as people who do not respect the law. Yet, with the Covid-19 crisis, they are now being praised as models of responsible behavior. The Mayor of Prato has publicly thanked them for enabling Prato to be one of the Italian cities less vulnerable to the virus in terms of contagions and deaths. In this sense, the shootings of Chinatown with no people on the streets, the same streets depicted as symbols of decadence, break a common stereotype. Furthermore, they let glimpse a new opportunity for constructing a different image of the city.

\subsection{A Critical Analysis of Landscape Stereotypes}

While it allowed the identification of recurrent subjects, themes, and spaces, the in-depth analysis of the selected six videos (see: Table 1) also led to the isolation of different 'narrations' of the city of Prato and the basic elements of its 'multiple identities'. These 
Table 1 List of the selected videos. Source: retrieved from YouTube on April 10th, 2020

\begin{tabular}{l|l|l}
\hline No. & Title and URL & Year \\
\hline 1 & $\begin{array}{l}\text { Blebla }- \text { Prato } \\
\text { https://youtu.be/lwsacE4JEQ4 }\end{array}$ & 2012 \\
\hline 2 & $\begin{array}{l}\text { Prato 1981 } \\
\text { https://youtu.be/vr3ZRinWhQ8 }\end{array}$ & 2007 \\
\hline 3 & $\begin{array}{l}\text { La Chinatown di Prato - Piazza Pulita 11 ott 2013 } \\
\text { https://youtu.be/pUa4GwOrW98 }\end{array}$ & 2013 \\
\hline 4 & $\begin{array}{l}\text { Noi non siamo un virus. Viaggio a Prato, nella Cina italiana discriminata per il } \\
\text { Coronavirus } \\
\text { https://youtu.be/xnvUsQ3QT9k }\end{array}$ & 2020 \\
\hline 5 & $\begin{array}{l}\text { Prato - Piccola Grande Italia } \\
\text { https://youtu.be/4SuAl7jAsiI }\end{array}$ & 2016 \\
\hline 6 & $\begin{array}{l}\text { Coronavirus, Matteo Biffoni (Sindaco di Prato): “Siamo pronti a prendere } \\
\text { ulteriori misure” } \\
\text { https://youtu.be/WSCn2xB_Te4 }\end{array}$ & 2020 \\
\hline
\end{tabular}

narrations rely on rooted stereotypes partly linked to each other, such as those related to Prato's industrial identity, the threat of immigration, and the nostalgia for the past. Besides, aesthetic stereotypes are emerging that depict Prato as a beautiful city and a city of culture.

The first notable finding is that most of the spatial references in the six videoswith due differences depending on the focal theme-relate to spaces and symbols that are not directly connected with the city's industrial identity. Moreover, the majority of them are cultural sights, either related to Prato's pre-modern history (i.e., the Bacchino Fountain, the Cathedral of St. Stephen, the Church of St. Domenico, the City walls, the Emperor's Castle, the Monument to Francesco Datini, and the Praetorian Palace) or modern and contemporary art and culture (i.e., the Exegi Monumentum Aere Perennius, the Mazzocchio, the Metastasio Theatre, Moore's sculpture Square Form with Cut, the Pecci Amphitheatre, and the Pecci Centre for Contemporary Art). Among others, the Textile Museum, together with the Lazzerini Library, is part of the Campolmi Pole, a symbol of Prato's industrial origins and an exemplar of industrial archaeology. Besides, the Buddhist Temple_-namely a sign of the presence of the Chinese community and social change towards multiculturalization - also finds space. On the other hand, Chinatown is the most referenced city place, while other symbolic places remain in the background (e.g., the City Hall, Duomo Square, the Lungobisenzio Stadium, Magnolfi Street, Mazzoni Street, Mercatale Square, Slaughterhouses Square, and Town Hall Square). Industrial sites, instead, are mostly referenced to trace back space to the discourse on Chinese immigration: in particular, Chinese factories in 'Macrolotto 0'-that is, Chinatown — and 'Macrolotto 1' are used as a background to characterize the way of working and living within the Chinese community. 
The subjects in the videos can be easily clustered based on their ethnic origins, namely Italians and Chinese. Two remarks are worth making concerning the processes of cultural hybridization, which are revealed by the-either explicit or implicit-references to two common stereotypes. The term cultural hybridization refers to "external flows", related to globalization, which "interact with internal flows producing a unique cultural hybrid that combines their elements" (Ritzer 2010, p. 255; on this concept see: Appadurai 1996). On the one hand, we find Italian people, interviewed on the road, who speaks with a Southern dialectal inflection. This phenomenon is related to inward migrations, dating back to the years of economic boom, in the 1950s and the 1960s. Today, the nephews of the first generations of migrants are full citizens of Prato, even if they maintain a link with their origins, indeed, developing a hybrid identity - as the urban rapper Blebla says, in video 1, "half Tuscan, half Southerner" (mezzo Toscano, mezzo terrone). On the other hand, we have a sharp contrast between Chinese workers interviewed at the workplace, who do not speak Italian, and the Chinese young people speaking Italian fluently that appear in videos 1 and 4 to break a common stereotype (no Italiano) and testify an ongoing process of hybridization.

Figure 10 gives an idea of how the 'Chinese question' is thematized. The map relates themes (nodes) to videos (cases) to identify thematic patterns.

The comparison between the two central patterns is highly significant. The two related videos, in fact, are based on journalistic reportages launched within the same tv program, on a national tv channel, but thematize the question differently. Video 3 reproduces common stereotypes related to the idea of Chinese factories as places of illegality-i.e., firms working 24 hours a day, organized as factories-dormitories, making systematic use of undeclared work, not paying taxes, and transferring wealth abroad through money transfers. The correspondent defines them as "the first enemy" -of Italian entrepreneurs, in the grip of crisis. In this video, Chinatown is the place where "expensive cars" run, driven by Chinese people. On the other hand, Video 4, dealing with Coronavirus in the early days of contagion, attempts to break an emerging stereotype,

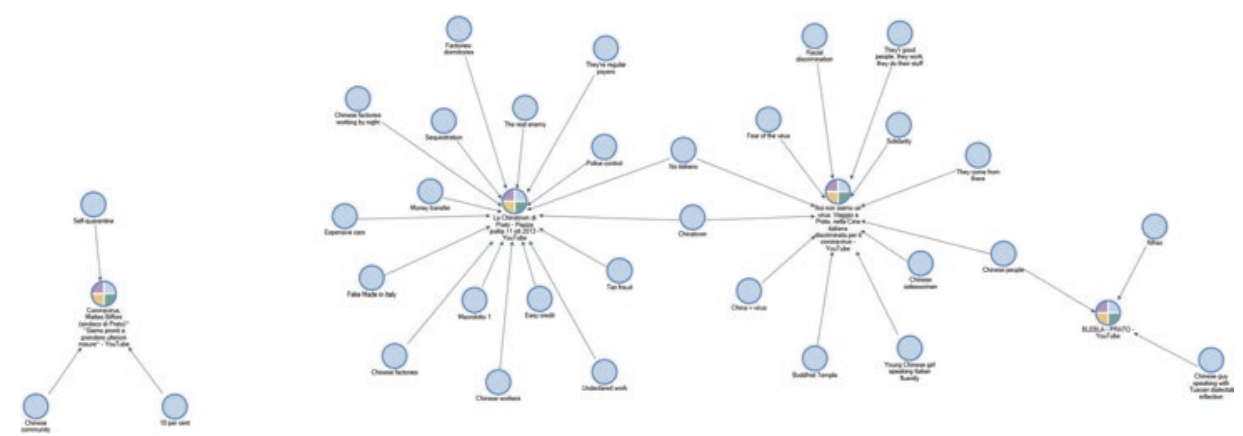

Fig. 10 Map of thematizations of the 'Chinese question' Source authors' processing of the texts of selected articles retrieved from YouTube on April 10th, 2020. 
expressed by the equivalence "China = virus". To give strength to the main argumentthat is, "We [Chinese people] are not a virus"-it reports the testimony of a Chinese girl speaking Italian fluently. Chinatown, with no people on the streets, because of their rigidly adhering to self-imposed quarantine, becomes the place of virtuosity.

These examples reveal that the definition of the identity of the city relies on how the local community deals with its multiple identity sources. Among them are not only ethnic sources but also cultural ones. The latter, in particular, play a crucial role in mediating between emotional ties to the past and a pragmatic look at the future.

\section{Lines of Hybridization-Refining the Research Agenda}

This chapter has dealt with a well-known and widely studied case, that is, the city of Prato. The great availability of studies on this subject, certainly, is an added value; on the other hand, it makes it difficult to deviate from pre-determined and well-established binaries. This seems to produce effects of path-dependence in academic research, which, as such, developed around a central theme, that is, Prato as a textile industrial district, with its economic, social, and-increasingly-environmental and health implications. The review of academic literature conducted in Sect. 3, however, revealed an unsuspected complexity of this city, which has undergone a profound transformation, bringing with it problems of social cohesion and sustainable development.

That said, the analysis of the public discourse, as conveyed by Internet videos, revealed that academic research, overall, has since now failed to grasp the inherent meanings of change just like the local community has not been able to deal with the mutations of its identity. The resilience of established stereotypes, associated with a nostalgic attachment to the past, is proof of that.

Nevertheless, the images disseminated through the Internet videos clearly show that this process is accompanied by a new geography of the places, landscapes, and spaces of the city, redrawn by the flows and settlements of people, especially new Chinese immigrants.

As highlighted, immigration is the most critical issue. It receives a high priority in social research and catches the attention of mass media, probably because it is perceived as a point of conjunction between the lost past and an uncertain future. Chinatown is the place where the changes related to immigration processes come to life. By the time, it is a settled and lively pole of attraction in Prato's polycentric development model. The experience of the Covid-19 pandemic further confirmed this fact.

On the other hand, a discourse that gives expression to Prato's artistic vocation is gaining space. As a result, aesthetic symbols related to arts and cultural heritage are gradually breaking the monopoly of material symbols related to industrial production.

This leaves room for the construction of a new imaginary, which, even in the references to places and landscapes, is projected towards the future, using cultural hybridization as a driver for change. 
To conclude, what emerges is that different lines of hybridization are active that are reconfiguring structure and functions, as well as spaces and symbols, of the city of Prato. These are economic, social, and, indeed, cultural lines of hybridization. Along these lines, academic research should develop new paths of inquiry.

\section{References}

Adamo, S. (2016). The Crisis of the Prato industrial district in the works of Edoardo Nesi: A blend of nostalgia and self-complacency. Modern Italy, 21(3), 245-259.

Appadurai, A. (1996). Modernity at large: Cultural dimensions of globalization. Minneapolis, MN-London: University of Minnesota Press.

Bagnasco, A. (1977). Tre Italie. La problematica territoriale dello sviluppo italiano. Bologna: Il Mulino.

Bailey, D., Bellandi, M., Caloffi, A., \& De Propris, L. (2010). Place-renewing leadership: Trajectories of change for mature manufacturing regions in Europe. Policy Studies, 31(4), 457-474.

Baldassar, L., \& Raffaetà, R. (2018). It's complicated, Isn't It: Citizenship and ethnic identity in a mobile world. Ethnicities, 18(5), 735-760.

Barbu, M., Dunford, M., \& Weidong, L. (2013). Employment, entrepreneurship, and citizenship in a globalised economy: The Chinese in Prato. Environment and Planning A: Economy and Space, 45(10), 2420-2441.

Bazeley, P., \& Jackson, K. (2013). Qualitative data analysis with NVivo (2nd ed.). London: Sage.

Becattini, G. (1962). Il concetto di industria e la teoria del valore. Torino: Bollati Boringhieri.

Becattini, G. (1979). Dal 'settore' industriale al 'distretto' industriale. Alcune considerazioni sull'unità d'indagine dell'economia industriale. Rivista di Economia e Politica Industriale, 1, $7-21$.

Becattini, G. (Ed.). (1987). Mercato e forze locali: il distretto industriale. Bologna: Il Mulino.

Becattini, G. (Ed.). (1997). Prato. Storia di una città. 4. Il distretto industriale (1943-1993). Firenze: Le Monnier.

Becattini, G. (2000). Il bruco e la farfalla. Prato nel mondo che cambia (1954-1993). Firenze: Le Monnier.

Becattini, G. (2004). Industrial districts: A new approach to industrial change. Cheltenham, UK: Edward Elgar.

Bellandi, M., De Propris, L., \& Santini, E. (2019). An evolutionary analysis of industrial districts: The changing multiplicity of production know-how nuclei. Cambridge Journal of Economics, 43(1), 187-204.

Bellandi, M., \& Russo, M. (Eds.). (1994). Distretti industriali e cambiamento economico locale. Torino: Rosenberg \& Sellier.

Bellandi, M., \& Santini, E. (2019). Territorial servitization and new local productive configurations: The case of the textile industrial district of Prato. Regional Studies, 53(3), 356-365.

Bellandi, M., Santini, E., \& Vecciolini, C. (2018). Learning, unlearning and forgetting processes in industrial districts. Cambridge Journal of Economics, 42(6), 1671-1685.

Berardi, C., Fibbi, D., Coppini, E., Renai, L., Caprini, C., Agata Scordo, C. V., et al. (2019). Removal efficiency and mass balance of polycyclic aromatic hydrocarbons, phthalates, ethoxylated alkylphenols and alkylphenols in a mixed textile-domestic wastewater treatment plant. Science of the Total Environment, 674, 36-48. 
Bessi, C., Lombardi, L., Meoni, R., Canovai, A., \& Corti, A. (2016). Solid recovered fuel: An experiment on classification and potential applications. Waste Management, 47, 184-194.

Bracci, F., \& Valzania, A. (2016). Hidden selectivity: Irregular migrants and access to sociohealth services in a heated local context. Cambio. Rivista sulle Trasformazioni Sociali, 5(10), 141-148.

Brusco, S. (1989). Piccole imprese e distretti industriali. Una raccolta di saggi. Torino: Rosenberg \& Sellier.

Caranci, N., Biggeri, A., Grisotto, L., Pacelli, B., Spadea, T., \& Costa, G. (2010). L'indice di deprivazione italiano a livello di sezione di censimento: definizione, descrizione e associazione con la mortalità. Epidemiologia e Prevenzione, 34(4), 167-176.

Ceccagno, A. (2015). The mobile emplacement: Chinese migrants in italian industrial districts. Journal of Ethnic and Migration Studies, 41(7), 1111-1130.

Chaminade, C., Bellandi, M., Plechero, M. \& Santini, E. (2019). Understanding processes of path renewal and creation in thick specialized regional innovation systems. Evidence from two textile districts in Italy and Sweden. European Planning Studies, 27(10), 1978-1994.

Chellini, E., Cherubini, M., Chetoni, L., Seniori Costantini, A., Biggeri, A., \& Vannucchi, G. (2002). Risk of respiratory cancer around a sewage plant in Prato, Italy. Archives of Environmental Health, 57(6), 548-553.

Chellini, E., Martino, G., Grillo, A., Fedi, A., Martini, A., Indiani, L., et al. (2015). Malignant mesotheliomas in textile rag sorters. Annals of Occupational Hygiene, 59(5), 547-553.

Chen, C. (2015). Made in Italy (by the Chinese): Migration and the rebirth of textiles and apparel. Journal of Modern Italian Studies, 20(1), 111-126.

Cincinelli, A., Del Bubba, M., Martellini, T., Gambaro, A., \& Lepri, L. (2007). Gas-particle concentration and distribution of n-alkanes and polycyclic aromatic hydrocarbons in the atmosphere of Prato (Italy). Chemosphere, 68(3), 472-478.

Cincinelli, A., Mandorlo, S., Dickhut, R. M., \& Lepri, L. (2003). Particulate organic compounds in the atmosphere surrounding an industrialised area of Prato (Italy). Atmospheric Environment, 37(22), 3125-3133.

Cincinelli, A., Stefani, A., Seniori Costantini, S., \& Lepri, L. (2004). Characterization of N-Alkanes and PAHS in PM10 Samples in Prato (Italy). Annali di Chimica, 94(4), 281-293.

Crocetti, E., Bernini, G., Tamburini, A., Miccinesi, G., \& Paci, E. (2002a). Incidence and survival cancer trends in children and adolescents in the Provinces of Florence and Prato (Central Italy), 1985-1997. Tumori Journal, 88(6), 461-466.

Crocetti, E., Ciatto, S., \& Zappa, M. (2001). Prostate cancer: Different incidence but not mortality trends within two areas of Tuscany, Italy [2]. Journal of the National Cancer Institute, 93(11), 876-877.

Crocetti, E., Miccinesi, G., Paci, E., \& Cislaghi, C. (2002b). What Is hidden behind urban and semiurban cancer incidence and mortality differences in Central Italy? Tumori Journal, 88(4), 257-261.

Dei Ottati, G. (2009). An industrial district facing the challenges of globalization: Prato Today. European Planning Studies, 17(12), 1817-1835.

Dei Ottati, G. (2014). A transnational fast fashion industrial district: An analysis of the Chinese businesses in Prato. Cambridge Journal of Economics, 38(5), 1247-1274.

Edler, D., Jenal, C., \& Kühne, O. (2020). Modern approaches to the visualization of landscapesAn introduction. In D. Edler, C. Jenal, \& O. Kühne (Eds.), Modern approaches to the visualization of landscapes (pp. 3-15). Wiesbaden: Springer VS.

Fibbi, D., Doumett, S., Colzi, I., Coppini, E., Pucci, S., Gonnelli, C., et al. (2011). Total and hexavalent chromium removal in a subsurface horizontal flow (h-SSF) constructed 
wetland operating as post-treatment of textile wastewater for water reuse. Water Science and Technology, 64(4), 826-831.

Fibbi, D., Doumett, S., Lepri, L., Checchini, L., Gonnelli, C., Coppini, E., et al. (2012). Distribution and mass balance of hexavalent and trivalent chromium in a subsurface, horizontal flow (SF-h) constructed wetland operating as post-treatment of textile wastewater for water reuse. Journal of Hazardous Materials, 199-200, 209-216.

Fioretti, G. (2002). Information structure and behaviour of a textile industrial district. Journal of Artificial Societies and Social Simulation, 4(4), 123-135.

Furferi, R., \& Gelli, M. (2010). Yarn strength prediction: A Practical model based on artificial neural networks. Advances in Mechanical Engineering, 2010, 1-11.

Furferi, R., \& Governi, L. (2011). Prediction of the spectrophotometric response of a carded fiber composed by different kinds of coloured raw materials: An artificial neural network-based approach. Color Research \& Application, 36(3), 179-191.

Iommi, S., \& Marinari, D. (2000). Mobilità residenziale e pendolarismo in Toscana. Firenze: IRPET.

Krause, E. (2015). Fistful of tears: Encounters with transnational affect, Chinese Immigrants and Italian Fast Fashion. Cambio. Rivista sulle Trasformazioni Sociali, 5(10), 27-40.

Kühne, O. (2018). Landscape and power in geographical space as a social-aesthetic construct. Dordrecht: Springer International Publishing.

Kühne, O. (2019). Landscape theories: A brief introduction. Wiesbaden: Springer VS.

Kühne, O. (2020). The social construction of space and landscape in internet videos. In D. Edler, C. Jenal, \& O. Kühne (Eds.), Modern approaches to the visualization of landscapes (pp. 121137). Wiesbaden: Springer VS.

Kühne, O. \& Bellini, A. (2019). Landscape conflicts and the making of contemporary European Societies: A dialogue with Olaf Kühne, Cambio. Rivista sulle Trasformazioni Sociali, 9(18), published online on March 20th, 2020.

Kühne, O., \& Jenal, C. (2020). The threefold landscape dynamics-Basic considerations, conflicts and potentials of virtual landscape research. In D. Edler, C. Jenal, \& O. Kühne (Eds.), Modern approaches to the visualization of landscapes (pp. 389-402). Wiesbaden: Springer VS.

Kühne, O., Weber, F., \& Berr, K. (2019). The productive potential and limits of landscape conflicts in Light of Ralf Dahrendorf's Conflict Theory. SocietàMutamentoPolitica, 10(19), 77-90.

Lan, T. (2015). Industrial district and the multiplication of labour: The Chinese Apparel Industry in Prato. Italy. Antipode, 47(1), 158-178.

Lan, T., \& Zhu, S. (2014). Chinese Apparel Value Chains in Europe: Low-end fast fashion, regionalization, and transnational entrepreneurship in Prato, Italy. Eurasian Geography and Economics, 55(2), 156-174.

Lazzeretti, L., \& Capone, F. (2017). The transformation of the prato industrial district: An organisational ecology analysis of the co-evolution of Italian and Chinese Firms. Annals of Regional Science, 58(1), 135-158.

Linke, S. (2020). Landscape in internet pictures. In D. Edler, C. Jenal, \& O. Kühne (Eds.), Modern approaches to the visualization of landscapes (pp. 139-156). Wiesbaden: Springer VS.

Loda, M., Kühne, O., \& Puttilli, M. (2020). The social construction of Tuscany in the German and English speaking world-Presented by the analysis of internet images. In D. Edler, C. Jenal, \& O. Kühne (Eds.), Modern approaches to the visualization of landscapes (pp. 157-171). Wiesbaden: Springer VS.

Lubello, C., Caffaz, S., Mangini, L., Santianni, D., \& Caretti, C. (2007). MBR pilot plant for textile wastewater treatment and reuse. Water Science and Technology, 55(10), 115-124.

Lubello, C., \& Gori, R. (2004). Membrane bio-reactor for advanced textile wastewater treatment and reuse. Water Science and Technology, 50(2), 113-119. 
Marshall, A. (1890). Principles of economics. London: Macmillan.

Milanesi, M., Guercini, S., \& Waluszewski, A. (2016). A Black Swan in the District? An IMP perspective on immigrant entrepreneurship and changes in industrial districts. IMP Journal, 10(2), 243-259.

Modesti, P. A., Calabrese, M., Malandrino, D., Colella, A., Galanti, G., \& Zhao, D. (2017a). New findings on type 2 diabetes in first-generation chinese migrants settled in Italy: Chinese in Prato (CHIP) Cross-Sectional Survey. Diabetes/Metabolism Research and Reviews, 33(2), e2835.

Modesti, P.A., Calabrese, M., Marzotti, I., Bing, H., Malandrino, D., Boddi, B., Castellani, S., \& Zhao, D. (2017b). Prevalence, awareness, treatment, and control of hypertension among chinese first-generation migrants and Italians in Prato, Italy: The CHIP Study. International Journal of Hypertension, 2017.

Modesti, P.A., Calabrese, M., Perruolo, E., Bussotti, A., Malandrino, D., Bamoshmoosh, M., Biggeri, A., \& Zhao, D. (2016a). Sleep history and hypertension burden in first-generation Chinese Migrants Settled in Italy: The Chinese in Prato Cross-Sectional Survey. Medicine (United States), 95(14).

Modesti, P. A., Colella, A., \& Zhao, D. (2016b). Atrial Fibrillation in first generation Chinese migrants living in Europe: A proof of concept study. International Journal of Cardiology, 215, 269-272.

Molina, J. L., Martínez-Cháfer, L., Molina-Morales, F. X., \& Lubbers, M. J. (2018). Industrial districts and migrant enclaves: A model of interaction. European Planning Studies, 26(6), $1160-1180$.

Munkholm, L. (2018). Creating a new type of labour law enforcer: The law technician in Prato. Journal of Law and Society, 45(4), 538-562.

Papadimitriou, F. (2020). Visualization of future landscapes, postmodern cinema and geographical education. In D. Edler, C. Jenal, \& O. Kühne (Eds.), Modern approaches to the visualization of landscapes (pp. 351-369). Wiesbaden: Springer VS.

Pizzo, A. M., Chellini, E., \& Seniori Costantini, A. (2011). Lung cancer risk and residence in the neighborhood of a sewage plant in Italy. A Case-Control Study. Tumori Journal, 97(1), 9-13.

Pratesi, G., Zoppi, M., Vaiani, T., \& Calastrini, F. (2007). A morphometric and compositional approach to the study of ambient aerosol in a medium industrial town of Italy. Water, Air, and Soil Pollution, 179(1-4), 283-96.

Raffaetà, R., Baldassar, L., \& Harris, A. (2016). Chinese immigrant youth identities and belonging in Prato, Italy: Exploring the intersections between migration and youth studies. Identities, 23(4), 422-437.

Ricatti, F., Dutto, M., \& Wilson, R. (2019). Ethnic enclave or transcultural edge? Reassessing the Prato district through digital mapping. Modern Italy, 24(4), 369-381.

Riccardi, M., Milani, R., \& Camerini, D. (2019). Assessing money laundering risk across regions. An application in Italy. European Journal on Criminal Policy and Research, 25(1), 21-43.

Ritzer, G. (2010). Globalization: A basic text. Malden, MA: Wiley-Blackwell.

Schiavoni, S., D'Alessandro, F., \& Conte, A. (2015). The contribution of LIFE+ NADIA project on the implementation of the European Directive on Environmental Noise. Noise Mapping, 2(1), $13-30$.

Seniori Costantini, A., Martini, A., Puliti, D., Ciatto, S., Castiglione, G., Grazzini, G., et al. (2008). Colorectal cancer mortality in two areas of Tuscany with different screening exposures. Journal of the National Cancer Institute, 100(24), 1818-1821.

Statistical Office of the Municipality of Prato. (2015). Progetto URBES 2015. Le aree di disagio socio-economico analizzate attraverso un indice di deprivazione. Retrieved 23rd February 2020 from http://statistica.comune.prato.it/. 
Tarantini, M., Dominici Loprieno, A., Cucchi, E., \& Frenquellucci, F. (2009). Life cycle assessment of waste management systems in Italian Industrial Areas: Case Study of 1st Macrolotto of Prato. Energy, 34(5), 613-622.

Testa, F., Nucci, B., Iraldo, F., Appolloni, A., \& Daddi, T. (2017). Removing obstacles to the implementation of LCA among SMEs: A collective strategy for exploiting recycled wool. Journal of Cleaner Production, 156, 923-931.

Trigilia, C. (1986). Grandi partiti e piccole imprese. Bologna: Il Mulino.

Valsecchi, S., Rusconi, M., Mazzoni, M., Viviano, G., Pagnotta, R., Zaghi, C., et al. (2015). Occurrence and Sources of Perfluoroalkyl Acids in Italian River Basins. Chemosphere, 129, $126-134$.

Verdini, G., \& Russo, E. (2019). The Chinese in Southern Europe: Has urban regeneration addressed their new form of clustering? Documents d'Anàlisi Geogràfica, 65(1), 163.

Viesti, G. (2000). Come nascono i distretti industriali. Bari: Laterza.

Visioli, C. B., Zappa, M., Ciatto, S., Iossa, A., \& Crocetti, E. (2004). Increasing trends of cervical adenocarcinoma incidence in Central Italy despite extensive screening programme, 1985-2000. Cancer Detection and Prevention, 28(6), 461-464.

Andrea Bellini is an Assistant Professor of Sociology at the University of Florence, Italy. He writes on middle classes, creative labor, professions, and, more generally, on issues of economic and social regulation. He has published two books in the Italian language: Il puzzle dei ceti medi (2014, FUP); Una professione plurale. Il caso dell'avvocatura fiorentina (2017, with F. Alacevich, A. Tonarelli, FUP). His recent works include: Small Firms and the External Context: Embeddedness Versus Dependency (2020, with V. Fortunato, Palgrave); Not Only Riders. The Uncertain Boundaries of Digital Creative Work as a Frontier for Emerging Actors in Interest Representation (2019, with S. Lucciarini, in PaCo); Professions Within, Between and Beyond. Varieties of Professionalism in a Globalising World (2018, with L. Maestripieri, in Cambio).

Laura Leonardi is a Professor of Sociology at the "Cesare Alfieri" School of Political Science at the University of Florence. Since 2013 to date, she is Director of CESVI (Centre for European Studies on Local and Regional Development) at the Department of Political Science and Sociology in Florence. Her research interests are social inequalities and social citizenship, labor and welfare, social theory, the impact of globalization and Europeanization on local societies. Among her most recent publications: Ralf Dahrendorf. Between Social Theory and Political Praxis, Palgrave (2020 with Olaf Kühne); Social citizenship and inequalities. Is there a future for a social Europe? In Social challenges for Europe: Addressing failures and perspectives or the European project, pp. 189-204, Bologna: Il Mulino (2019 with G Scalise, eds).; Reddito di base e diseguaglianze sociali. Una questione di chances di vita. Iride, vol. XXXII, pp. 325-337, 2019.; Ipotesi di quadratura del cerchio. Diseguaglianze, chances di vita e politica sociale in Ralf Dahrendorf. SocietàMutamentoPolitica, vol. 10, pp. 127-139, 2019. 